\title{
Mineral Resource Depletion Assessment: Alternatives, Problems, Results
}

\author{
Tatiana Ponomarenko ${ }^{1}$, Marina Nevskaya ${ }^{1, *}$ and Izabela Jonek-Kowalska ${ }^{2} \mathbb{D}$ \\ 1 Department of Organization and Management, Saint-Petersburg Mining University, 199106 Saint-Petersburg, \\ Russia; Ponomarenko_TV@pers.spmi.ru \\ 2 Department of Economics and Informatics, Silesian Technical University, 41-800 Zabrze, Poland; \\ izabela.jonek-kowalska@polsl.pl \\ * Correspondence: Nevskaya_MA@pers.spmi.ru or ma.nevsk@yandex.ru; Tel.: +7-921-358-3380
}

Citation: Ponomarenko, T.;

Nevskaya, M.; Jonek-Kowalska, I. Mineral Resource Depletion Assessment: Alternatives, Problems, Results. Sustainability 2021, 13, 862. https://doi.org/10.3390/su13020862

Received: 25 November 2020 Accepted: 13 January 2021 Published: 16 January 2021

Publisher's Note: MDPI stays neutral with regard to jurisdictional clai$\mathrm{ms}$ in published maps and institutional affiliations.

Copyright: (C) 2021 by the authors. Licensee MDPI, Basel, Switzerland. This article is an open access article distributed under the terms and conditions of the Creative Commons Attribution (CC BY) license (https:// creativecommons.org/licenses/by/ $4.0 /)$.

\begin{abstract}
The depletion of non-renewable natural resources (primarily mineral and energy resources) and its assessment is a problem that is analyzed based on the concept of sustainable development. Mineral resource depletion assessment is particularly important for resource-based economies. It provides for assessing the impact of mineral asset disposal that results from the suspension or termination of operations conducted by a mining company due to insurmountable circumstances. The results of such an event will be manifested at the national, regional, and local levels and felt by mining companies, suppliers, workers, the population of the territory, and other stakeholders. The study clarifies the attributes and essence of mineral resource depletion, analyzes the advantages and limitations of the existing tools for assessing mineral resource depletion, identifies depletion factors, describes a methodology for assessing mineral resource depletion, and contains a case study of a tin deposit. The results of the study contribute to the development of the theory on the depletion of non-renewable natural resources. They provide for assessing losses to social wellbeing that can be caused by stopping the use of profitable mineral reserves.
\end{abstract}

Keywords: mineral resources; mineral assets; non-renewable resources; depletion; sustainable development; mineral resource rent; cost-benefit analysis

\section{Introduction}

The paradigm of sustainable development (SD) has been understood by the majority of developed and developing countries. However, still under discussion is what kind of contribution is made by non-renewable resources to the SD of countries whose economies largely depend on their availability, quality, and market demand, and are developed based on the efficient and rational use of mineral resources [1].

Among different countries, there is no single opinion as to the issue of mineral resource depletion (MRD); this can be seen in the opposing views surrounding the roles that mineral resources have played in the sustainable development of individual countries and the global economic system in general. These views are reflected both in the state policies of economically developed countries and developing resource-based economies (RBEs) and in the methodologies for assessing the depletion of non-renewable natural resources.

For example, the point concerning the use of natural resources that all the EU members agree on is that both economic growth and environmental protection are of equal importance [2]. It is possible to achieve goals in these areas only when there is weak sustainability, with reproduced capital and human capital dominating and the share of natural capital being insignificant. The environment and energy are shared competences between the EU and its member countries, and the main priorities of the EU's development policy are primarily connected with energy resources, with almost $70 \%$ of them being purchased from third parties, including Russia [3]. With regard to energy resources, the EU has been consistently working on reducing greenhouse gas emissions and replacing 
fossil fuels with renewable energy sources [4-6]. In particular, the EU's Climate and Energy Framework for the period from 2020 to 2030 plans to reduce greenhouse gas emissions by $40 \%$ (compared to the levels of the year 1990) and reach the target of at least $27 \%$ renewable energy sources [3], which should improve the situation of the EU's dependence on countries exporting energy (primarily Russia).

Regarding the use of other mineral resources, the policies of the EU member countries are based on the general principles of the circular economy, which implies a transition to a closed-loop model that provides for the continual use of raw materials and makes it possible to involve production waste, secondary raw materials, and substitutes for natural resources in processing. However, as noted by the authors of [7], the mining sector (geological exploration, production, and primary processing) stands out from all the other sectors in this model as it does not solve the MRD problem. As the main strategies for successful development, such options are proposed as a complete rejection of the use of mineral resources and their replacement with artificial substitutes [8], accumulating the most in-demand metals (for example, rare earth elements) in the form of so-called metal banks [9], and using the most efficient technology in processing imported mineral resources to create high added value in developed countries.

Among RBEs, Russia provides the biggest and most vivid example of using mineral resources and solving methodological issues in this area [10]. After the collapse of the USSR, the MRD problem became acute in Russia, with its resource portfolio having twentyone weak points, i.e., the supply of these resources did not meet demand [11]. MRD is considered by the country from the perspective of long-term supply of mineral and energy resources [12]; therefore, in contrast to the EU countries, the priority is traditionally given to the exploration industry. In the state program titled "Reproduction and use of natural resources" [13], the key goal is formulated, which is to ensure that the resources being extracted are fully compensated for by new mineral and energy reserves found in the course of prospecting and exploration operations. That is, the suggested solution of the MRD problem is the physical replacement of old mineral reserves with new ones as a result of expanded reproduction. The MRD problem in RBEs can lead to a decrease in production efficiency in both countries that extract resources and countries that consume them. This makes mineral resource depletion an issue of significance, along with such issues as using mineral resources in production, mineral resource monetization, and generating both direct and multiplicative income.

Despite the fact that there are many methodological approaches (mainly Western ones) to assessing MRD, the most popular methods are congruent with the SD concept developed by G. H. Bruntland [14]. Some methods are based on the principles of so-called strong sustainability, which means that mineral resources are limited and will not be available in the future [8]; hence, there is a radical option that implies a complete rejection of mining operations. Others are based on weak stability and define mineral resources as one of the forms of natural capital whose use should not lead to a decrease in total capital $[15,16]$.

Current methodological approaches to assessing MRD from the perspective of both strong and weak sustainability reflect the situation that is typical of economically developed countries which have a high share of renewable, human, and social capital, with their natural resources (including mineral ones) being limited.

The experience of countries with RBEs (for example, Russia, Kazakhstan, Mongolia, Kyrgyzstan, etc.), especially developing ones, shows that the economic significance of mineral resources is much higher for them than for industrially developed countries, including the mining industry itself and related industries. For example, in the Russian Federation, the share of oil and gas revenues in the country's GDP amounted to $41.0 \%$ of the total federal budget revenues in 2019 [17], and the share of mineral exports exceeded $65.0 \%$, with the majority (over $98 \%$ ) accounted for by fuel and energy products [18,19]. A similar situation can be seen in other RBEs $[20,21]$.

For RBEs, both the commissioning of new mineral deposits and the loss of mineral assets due to the suspension or termination of operations conducted by mining companies 
play an important role [22]. The results of these processes will be manifested at the national, regional, and local levels and felt by mining companies, suppliers, workers, the population of the territory, and other stakeholders. For countries whose economies are not resourcebased, the losses will be less significant at the national level because the structure of the economy in these countries is based on the exploitation of reproduced rather than natural capital. However, for the regional and local levels, such losses and damage can be catastrophic. It should be noted that, in addition to the impact on the economy, there are environmental and social impacts that should be considered in assessing MRD.

Mineral resources (MRs) and mineral assets (MAs) have a number of specific characteristics for the national economy and mining companies, respectively [23], and can be influenced by various depletion factors. On the one hand, MAs are characterized by the opportunity to create and increase value added (i.e., they have option characteristics), and, on the other hand, by a decrease in or a loss of their economic value under the influence of various factors. In terms of management and control, the owner of MAs is the government, while in terms of ownership and use, it is the operator or license holder, which makes it necessary to use MAs in an effective and rational way. In countries with RBEs, the use of MRs and MAs should be consistent with sustainable development goals [24].

A mineral asset is a broad notion that covers not only mineral deposits themselves but also various rights regarding their exploration, development, and mining, i.e., the blocks from which mining companies extract mineral resources are considered to be mineral assets. In most cases, mining implies conducting complex operations that require subsequent land rehabilitation as mining often alters the environment, sometimes damaging it significantly [25].

Regulations make attempts to define MAs (or property). Apart from mineral reserves, the following two assets are usually defined as MAs [26]:

(1) Rights, titles, or interests concerning the property held or acquired in connection with the exploration, development, extraction, or processing of minerals regardless of where this property is located;

(2) All of the equipment and infrastructure owned or acquired for the exploration, development, extraction, and processing of minerals, including mines and processing plants [27].

Physical factors of depletion are taken into account in feasibility studies when calculating mine life and production capacity. Economic factors of depletion are taken into account in a limited way (mainly when analyzing the resource conditions). The assessment of the influence of economic, social, and environmental factors is carried out under the current norms, standards, rules, prices, demand, the situation with the energy and transport infrastructure, the degree of government regulation, the form of ownership, etc.

The overwhelming majority of deposits are mined and operated for decades, with the exception of small precious metal deposits. Consequently, the influence of various factors can significantly increase, decrease, and change its direction over the course of time, which can lead to early termination of deposit operation, direct losses suffered by owners (mining companies and the government), and indirect losses suffered by related industries.

The objectives of the study are:

1. To conduct a comparative analysis of MRD assessment models.

2. To propose a method for assessing MRD based on comparative analysis and to test this method on a polymetallic ore deposit.

\subsection{Analysis of Approaches to the Depletion of Mineral Resources: The Essence of Mineral Resource Depletion}

In a broad sense, resource depletion is the result of an excess of resource consumption over its reproduction (physical depletion) [28]. For non-renewable resources (mineral and energy ones), depletion means a quantitative and qualitative deterioration of mineral reserves, resulting in their scarcity. From the viewpoint of the SD concept and its main thesis that SD can only be achieved when the satisfaction of current needs does not jeopardize 
the satisfaction of the needs of future generations [29], MRD is tantamount to limiting the access to MRs for future generations and making them suffer economic losses.

In the geological and economic aspect, the depletion of minerals is a decrease in initial reserves and a discrepancy between the norms for the extraction of natural resources and the needs of mankind (country, region, etc.) as a result of production costs (including processing costs in some cases) reaching the value of the produced economic effect, making the use of the natural resource socially and economically unprofitable [30]. This definition characterizes the depletion of MRs as primarily depending on objective natural and technological factors which limit the economic availability of the resource.

Economic depletion is a decrease in the economic return of a mineral resource $[9,28]$ that is caused by lost earnings which could be used for social development. For MRs, depletion entails a shortage of potential earnings; consequently, for the facilities being operated, MRD means the impossibility of obtaining real economic, environmental, and social results by the mining company or reaching social wellbeing associated with the use of MRs. The factors causing the depletion of MAs at mining facilities are much more diverse than those causing the depletion of MRs, and, as R. Cairns rightly notes [31], are in large part determined by the goals that society associates with the use or rejection of the use of mineral resources.

For example, the fact that the UK and Germany closed their last coal mines (in 2014 and 2015, respectively) is linked to EU environmental policies and the development of the renewable energy sector, which makes coal less often used in electricity generation $[32,33]$.

Royal Dutch Shell completely ceased oil production from the Brent field in the North Sea due to the fact that it was not competitive enough compared to production in other regions [34].

The largest oil field in Libya, El Sharara, was closed at the request of representatives of the Libyan tribes working there. After the pipeline connecting the field with the Zawiya oil refinery (the largest in the country) was shut down, all the Sharara wells, along with those at the nearby El Feel field, were suspended. Their daily production amounted to approximately 400 thousand barrels [35].

In Russia, several mines operated by Lovozersky GOK JSC have been closed due to inefficient processes and violations of occupational safety and health regulations [36]. The development of a barite deposit in Karelia has been stopped as it was declared unprofitable due to unfavorable hydrogeological conditions [37]. In these examples, depletion is connected with the goals of the community and the corporation; the mineral reserves themselves are preserved and can be used by future generations. Thus, the consequences of MRD can be witnessed in economic, environmental, and social spheres.

\subsection{Analysis of Approaches to the Depletion of Mineral Resources: Methods of Assessing MRD}

The problem of MRD has been studied for quite a long time, starting with the famous publication by $\mathrm{H}$. Hotelling titled "The economics of exhaustible resources" [38]. The model proposed by Hotelling for evaluating an exhaustible resource was based on the assumption that a resource is extracted in an optimal way in the conditions of perfect competition, zero costs, clearly defined property rights to resources, and a constant real interest rate. The optimal trajectory of mineral extraction was defined as a function of social wellbeing [39]. The author is reasonably recognized as the founder of the theory describing the optimal extraction of exhaustible resources [40]. However, due to the development of ecological economics, welfare economics, and depletion concepts, Hotelling's model was later modified taking into account a number of factors and revising its assumptions.

In academic and applied research, MRD is discussed by Solow [41], Adelman [15], El-Serafy [16], von Amsberg [8], Cairns [31], Boos [42], and others. Some researchers have shown that MRD assessment serves the tasks of managing MRs $[9,28]$ at the national level, which is reflected in the calculation methods used in different models. For example, the indices of adjusted net savings (ANS) and genuine progress (GPI), which are the most important SD indicators, attempt to assess MRD for the entire national economy [43-45]. 
In the frameworks of ANS and GPI, MRD is assessed using the concept of economic rent $[46,47]$. However, the methods for calculating economic rent are simplified and do not make it possible to distinguish it from income. Economic rent is calculated using a universal methodology for the macro and micro levels. However, calculations are based on different foundations [48]. For the macro level, economic rent can be defined as the excess of actual income over the average income in the industry. Therefore, value added is used as the main indicator. For the micro level, calculating economic rent is more complicated as it is very difficult to choose the correct foundation (normal profit) for calculation. Decades of research have not yielded satisfactory results [49].

In terms of comprehensiveness, the best analyses of MRD models can be found in $[28,50]$. Using uniform symbols for some parameters, Table 1 presents information on a range of MRD assessment models and methods [8,15,16,28,43,46,51-53].

Table 1. MRD assessment models and methods.

\begin{tabular}{|c|c|c|}
\hline Method & Equation & Variables \\
\hline $\begin{array}{c}\text { 1. World Bank method (annual rent } \\
\text { calculation; it is used to fix the values of } \\
\text { indicators used to calculate net savings) } \\
{[43,46]}\end{array}$ & $D p=\frac{\sum_{i=0}^{T} \frac{R}{(1+r)^{t}}}{T}$ & $\begin{array}{l}D p \text { is MRD, } R \text { is natural rent, } T \text { is the time remaining } \\
\text { until the resource is depleted, } r \text { is the discount rate. } \\
\qquad R=(P-C) \cdot Q \\
P \text { is the resource price, } C \text { is the average costs of } \\
\text { extracting the resource in the country, } Q \text { is production } \\
\text { volume, t is the assessment interval (a year). }\end{array}$ \\
\hline $\begin{array}{l}\text { 2. Method for finding the present value of } \\
\text { future income [52] }\end{array}$ & $D p=N P V=\left[\int_{0}^{T}\left[\left[p_{t} q_{t}-c_{t} q_{t}\right] e^{-r t}\right]\right] \frac{d t}{Q}$ & $\begin{array}{l}D p \text { - is MRD, NPV is the net present value from the use } \\
\text { of MRs, } p \text { and } c \text { are the market price and production } \\
\text { costs per unit, respectively, } r \text { is the discount rate, } Q \text { is } \\
\text { the amount of reserves, } q \text { is the annual production } \\
\text { volume, } T \text { is mine life (in this model, depletion is } \\
\text { defined as the exponential decay demonstrated by } \\
\text { natural reserves), } t \text { is the assessment interval (a year). }\end{array}$ \\
\hline \multicolumn{3}{|l|}{ 3. Net price method } \\
\hline 3.1. Excluding return on investment [51] & $N P=R=p-c$ & $\begin{array}{l}N P \text { is the annual net profit, } R \text { is rent in the current } \\
\text { period, } p \text { and } c \text { are the market price and production } \\
\text { costs per unit, respectively. }\end{array}$ \\
\hline $\begin{array}{l}\text { 3.2. Including the return on the total } \\
\text { amount of investments associated with } \\
\text { natural resource development [28] }\end{array}$ & $R=\frac{(p q-c q)-r\left(I_{D}+I_{E . D}-D e p\right)}{q}$ & \multirow{2}{*}{$\begin{array}{l}R \text { is rent in the current period, } I_{D} \text { is investments in the } \\
\text { fixed capital associated with mineral extraction, } I_{E . D} \text { is } \\
\text { investments in } R \mathcal{E} D \text { and exploration, Dep is } \\
\text { investment amortization, } q \text { is the annual production } \\
\text { volume, } p \text { and } c \text { are the market price and production } \\
\text { costs per unit, respectively, } r \text { is the discount rate equal } \\
\text { to the minimum rate of return on investment. }\end{array}$} \\
\hline $\begin{array}{l}\text { 3.3. Including return on investment } \\
\text { without taking into account that } \\
\text { associated with R\&D and exploration [28] }\end{array}$ & $R=\frac{(p q-c q)-r\left(I_{D}-D e p\right)}{q}$ & \\
\hline $\begin{array}{l}\text { 4. El-Serafy's method (net price method } \\
\text { with the division of income into savings } \\
\text { and the share that is consumed) [16] }\end{array}$ & $\begin{aligned} D p & =N P e^{-r t} \\
N P & =Y+D p\end{aligned}$ & $\begin{array}{c}D p \text { is MRD, NP is the annual net profit, } Y \text { is the } \\
\text { consumed income, } r \text { is the discount rate, } t \text { is the } \\
\text { assessment interval (a year). }\end{array}$ \\
\hline 5. Stable price method [8] & $\begin{array}{c}D p=P_{s}-c \\
\int_{0}^{\infty} q_{t} P_{s} e^{-r t} d t= \\
\int_{0}^{T} q_{t} c_{t} e^{-r t} d t+\int_{T}^{\infty} q_{t} P_{u} e^{-r t} d t\end{array}$ & $\begin{array}{l}D p \text { is MRD, } P_{s} \text { is the stable price, } P_{u} \text { is the price for the } \\
\text { renewable substitute, } q \text { is the annual production } \\
\text { volume, } T \text { is the time remaining until the resource is } \\
\text { depleted, } t \text { is the assessment interval (a year), } r \text { is the } \\
\text { discount rate, } p \text { and c are the market price and } \\
\text { production costs per unit, respectively. }\end{array}$ \\
\hline 6. Replacement cost method [53] & $D p=C_{m}-C$ & $\begin{array}{c}D p \text { is MRD, } C_{m} \text { is marginal costs and } C \text { is unit costs for } \\
\text { prospecting and exploration. }\end{array}$ \\
\hline 7. Transaction costs method $[15,28]$ & $D p=P_{T r}-c$ & $\begin{array}{l}D p \text { is MRD, } P_{T r} \text { is transaction costs, } c \text { is the production } \\
\text { costs per unit, respectively. }\end{array}$ \\
\hline $\begin{array}{l}\text { 8. Method for share valuation in the } \\
\text { mining sector [28] }\end{array}$ & $D p=\frac{S p N-d F_{a}}{Q}$ & $\begin{array}{c}D p \text { is MRD, } S p \text { is the market price of a share, } N \text { is the } \\
\text { number of shares on the market, } d \text { is the share of fixed } \\
\text { assets (fixed capital) in the company's assets, } F a \text { is the } \\
\text { value of the company's fixed assets, } Q \text { is the annual } \\
\text { amount of mined-out reserves. }\end{array}$ \\
\hline
\end{tabular}


An analysis performed by the authors showed that the first five methods are different versions of the income approach. The sixth method is connected to the cost approach. The seventh method is a comparative one (market approach). The eighth method can be called comprehensive as it includes elements of both the comparative and the income approaches. The drawbacks of the cost approach and the comparative approach that arise in MRD assessment were identified quite long ago [54], which makes it impossible to correctly apply them and adequately interpret their results. For example, it is necessary to calculate the marginal costs of extracting mineral resources based on ranking deposits (Model 6); it is necessary to have information on market transactions taking into account the fulfillment of the requirements concerning market prices (Model 7); and there are issues surrounding the complexity of the economic assessment of MAs in the value of the company's assets and obtaining different results due to the use of different methodological approaches (Model 8).

Therefore, the income approach should be used to estimate costs and to assess the depletion of MRs as it has a number of well-known advantages [55]. However, the main problem in applying the income approach to MRD assessment is the need to separate economic rent from the income obtained by the use of MRs. This is due to the fact that mining companies generate income only through the joint use of fixed assets (reproduced capital) and MAs (natural capital). By analyzing Models 1 to 5, it can be seen that natural rent is not completely separated from the total profit obtained from the use of MAs. In assessing MRD at the macro level or for mining companies with state participation (at the micro level), the separation of natural rent from the total income is not essential as it is used for calculation purposes only or is fully appropriated by the government. The only problem to solve is the distribution of economic rent between the present and future generations. For private companies operating mineral deposits, separating the natural rent from the income is fundamentally important since they use their own capital in the formation of income, the rent part of which should be appropriated by future generations and the rest of the income should be appropriated by the present generation represented by the owners of MAs. One of the options for the distribution of economic rent between generations is proposed by El-Serafy.

Russian studies on the subject first appeared in the 1960s. Since then, they have not considered MRD assessment as an independent issue as they were mainly focused on selecting the best option for starting to develop new deposits. At the same time, K.G. Gofman, A.S. Astakhov, T.A. Gatov, N.Ya. Lobanov, S.A. Kimelman, V.I. Nazarov, and others made significant contributions to the issue of economic assessment in the mineral sector. In the Soviet period, depletion was mainly viewed as the deterioration of the physical properties of mineral resources in a deposit, i.e., a decrease in the content of valuable components combined with losses and dilution arising from the extraction and processing of minerals, which ultimately lead to losses suffered by the country's economy. That is, depletion was assessed by the final direct and indirect results (consequences) [56].

By the 1990s, the economic assessment of MRD in Russia had developed into a substantial body of theory including various directions ranging from geological and economic assessment to the assessment of losses caused by the irrational use of MRs and the environmental impact of the mining sector. This was due to the fact that vast mineral and energy reserves were available for extraction, which led to evaluating MRs from the standpoint of maximizing income for the current generation rather than from that of assessing losses for future generations. However, the main principles of using MRs have always included rationality, comprehensive extraction and processing operations, reduction of ore loss and dilution, as well as mining and mineral processing waste utilization [57].

\section{Materials and Methods}

To assess the depletion of MAs caused by the termination of operations conducted by a mining company, a new methodology is proposed that is based on combining the methods for depletion assessment used in the income approach. It should be noted that the proposed methodology can only be used for MRD assessment at economically viable 
mining companies. In the version discussed here, the methodology can be applied to MAs consisting of only one mineral because complex ores require that the contribution of each mineral to costs and income should be taken into account, which makes the calculation procedure more difficult. It is assumed that ore reserves will be mined for a period that does not exceed 25 years, which does not require the use of complex tools for predicting the influence of depletion factors.

The methodology consists of two steps:

Step 1. Assessing specific depletion using rent per unit. Rent per unit (per 1 ton of reserves) is calculated using the net price equation (Model 3). The choice of model depends on the source of financing prospecting and exploration operations.

Step 2. Assessing total mineral asset depletion depending on the period of the suspension or termination of mining operations using the World Bank model (Model 1) or the present value of future income (Model 2). When the operations are stopped temporarily, the discrete summation of rent per unit according to Model 1 for the period of the shutdown is performed. If the operations are stopped permanently, Model 2 is applied with a continuous summation of rent per unit.

The example of a tin deposit was used to assess the depletion of MAs. The situation was modeled in which there is fixed capital and a decision is made to stop mining operations. The main characteristics of the deposit and the initial data for calculation are presented in the Results section.

\section{Results}

The Syrymbet tin deposit is the largest one in Central Asia. The development of the deposit began in 2001 but had to be stopped several times for various reasons. Tin is the main valuable component of ore in the deposit. According to the JORC international classification, the deposit contains 463.5 thousand tons of tin ore with an average tin content of $0.49 \%$ [58]. The estimated mine life of the first block is 14 years. The ore contains tungsten $(0.172 \%)$, silver $(4 \mathrm{~g} / \mathrm{t})$, gold $(0.15 \mathrm{~g} / \mathrm{t})$, molybdenum $(0.022 \%)$, and zinc $(0.026 \%)$ [58-60]. Thus, Syrymbet can be described as a polymetallic deposit with ores than contain rare metals. The fact that it is a fine-grain deposit containing associated minerals makes its ores difficult to process [61].

The goal of the project is to foster tin production in the Republic of Kazakhstan taking into account current environmental standards and the introduction of the most effective technological solutions. There are two options: the first one is a full production cycle (which includes mining, ore processing, and metal production) and the second one is concentrate production (which includes only mining and ore processing). The planned production and processing volume does not exceed one million tons of ore per year. In the future, the expansion of the production capacity of the facility is planned, increasing the production of tin up to six or eight thousand tons per year.

Tin-containing minerals, ore minerals, and rock-forming minerals have different densities as well as radiometric and flotation properties, which determines the beneficiation technology. Gravity concentration is the most advanced beneficiation method today. First, coarse ores are subjected to crushing, which is followed by dense medium separation. These stages provide for separating the major share of waste rock and reduce costs in subsequent concentration stages.

As Syrymbet is a complex deposit in terms of its geological and mineralogical properties, mining, beneficiation, and processing operations require individual solutions. To choose the right process flow sheet, R\&D was conducted over a period of several years, which resulted in classifying the ore as difficult to treat. It also resulted in choosing a process flow sheet based on gravity concentration methods that make it possible to produce concentrates with almost any content. The process flow sheet provides for the production of two types of fractions: a rich concentrate with a tin content of $45.32 \%$ and an intermediate product with a tin content of $4.90 \%$ with the following extraction of tin into a concentrate with a content of $56.1 \%$. When applying complex ore processing technology to the ores 
at the Syrymbet deposit, it is possible to produce concentrates with a high content of the valuable component (that exceeding $90 \%$ ).

Based on an analysis of the experience accumulated by Russian tin producers, common problems were identified that included major losses of the valuable component in slag, significant anthropogenic impact on the environment, energy-, labor-, and material-intensive products, and the absence of integrated process flow charts covering a full production cycle from mining to the output of high value-added products. These factors can suspend production and cause the depletion of MAs.

MRD can be demonstrated using the example of any of the valuable components of the run-of-mine and processed ore that are either not recovered and go into the tailings or are not used in a high value-added product. To analyze depletion at the Syrymbet deposit, data on the tin extracted there was used.

Geological and production conditions at mineral deposits include qualitative characteristics, quantitative indicators (the amount of reserves), and geological structures (modes of occurrence). Among the qualitative characteristics are the content of the valuable component in the ore, chemical composition, the structure of the ore body, and ore concentration properties.

The initial data are presented in Table 2 for two tin production options: a full cycle (metal production) and concentrate production [61]. All costs (\$ mln) are annual.

Table 2. Tin production indicators.

\begin{tabular}{|c|c|c|c|}
\hline Indicator & Unit & Full Cycle & Concentrate Production \\
\hline Production & Thousand tons per year & & 1000 \\
\hline Ore extraction costs & $\$ / \mathrm{t}$ & & 26.85 \\
\hline Concentration costs & $\$ / \mathrm{t}$ & & 3.18 \\
\hline Metallurgical processing costs & $\$ / \mathrm{t}$ & 9.27 & - \\
\hline Concentrate transportation costs & $\$ \mathrm{mln}$ & - & 3.28 \\
\hline $\begin{array}{l}\text { Payroll and insurance } \\
\text { (administration and management) }\end{array}$ & $\$ \mathrm{mln}$ & 3.26 & 2.47 \\
\hline Miscellaneous expenses & $\$ \mathrm{mln}$ & 5.73 & 4.15 \\
\hline Production costs & $\$ \mathrm{mln}$ & 54.42 & 44.39 \\
\hline Amortization & $\$ \mathrm{mln}$ & 7.48 & 5.43 \\
\hline Discount rate & $\%$ & 15 & 15 \\
\hline $\begin{array}{l}\text { Investments in ore production, } \\
\text { beneficiation, and processing }\end{array}$ & $\$ \mathrm{mln}$ & 104.8 & 76.1 \\
\hline Investments in prospecting and exploration & $\$ \mathrm{mln}$ & No data available & No data available \\
\hline
\end{tabular}

The calculations include an assessment of the specific and total depletion of the deposit in case a decision is made to stop operating the deposit.

Step 1. Assessing specific depletion using rent per unit. Rent per unit (per 1 ton of reserves) is calculated using the net price equation (Model 3).

The choice of a model depends on the source of financing prospecting and exploration operations. Model 3.1 is not used to calculate rent because marketable products are those that are produced through processing rather than mineral reserves themselves. Model 3.3 is not used either, as investments in prospecting and exploration were made over a long period and there is no reliable information covering this aspect. Therefore, Model 3.2 was chosen to make the calculations (Table 1).

$$
R=\frac{(p q-c q)-r\left(I_{D}+I_{E . D}-D e p\right)}{q}
$$


$I_{D}$ is investments in the fixed capital associated with mineral extraction, $I_{E . D}$ is investments in R\&D and exploration, Dep is investment amortization, and $r$ is the discount rate equal to the minimum rate of return on investment.

Step 2. Assessing total mineral asset depletion depending on the period of the suspension or termination of mining operations using Models 1 and 2. When the operations are stopped temporarily, the discrete summation of rent per unit according to Model 1 for the period of the shutdown can be used. If the operations are stopped permanently, Model 2 can also be used with a continuous summation of rent per unit (Table 3). The initial data (sales revenue, profit from sales, and net profit) were obtained from [58-60].

Table 3. Natural rent and total depletion of reserves at a tin deposit: calculation results.

\begin{tabular}{cccc}
\hline Indicator & Unit & Full Cycle & Concentrate Production \\
\hline Sales revenue & $\$ \mathrm{mln}$ & 84.65 & 71.01 \\
\hline Profit from sales & $\$ \mathrm{mln}$ & 30.22 & 26.62 \\
\hline Net profit & $\$ \mathrm{mln}$ & 24.54 & 21.8 \\
\hline Rent per one ton of reserves & $\$ / \mathrm{t}$ & $(30.22-0.15 \times 104.8) / 1000=14.5$ & $(26.62-0.15 \times 76.1) / 1000=15.205$ \\
\hline Total depletion of MAs based on NPV & $\$ \mathrm{mln}$ & 35.57 & 44.53 \\
\hline
\end{tabular}

\section{Discussion}

The differences in the depletion values that were calculated based on rent and NPV (Table 3) are explained by the differences in the calculation models. It should be noted that the option that implies concentrate production gives a more visible economic effect (NPV) and a higher value of rent consequently implies a higher value of depletion. Such results can be explained by additional investments in metallurgical processing amounting to 28.7 USD million and an increase in operating costs of 9.03 USD million. In addition, the need to develop and implement innovations in metallurgical processes due to their complexity, complex ores, and the lack of similar experience reduces the economic efficiency if the full cycle of production is used. Thus, if MRD is assessed based only on economic results (rent and NPV), only the influence of economic factors is reflected, and only direct economic effects are included, making this kind of assessment incomplete.

We believe that along with direct economic effects, the multiplier effect associated with related industries should also be considered. This requires a targeted study that will consider assessments made for individual countries [62,63].

The methods for assessing non-renewable resource depletion that were analyzed (except for El-Serafy's method) are based on the fact that the opportunity of making a profit from the use of an exhaustible natural resource today deprives future generations of making a profit in the future because non-renewable resources cannot be replenished in a reasonable period of time (the life of several generations). The limitations of the methods are as follows:

First, the profit made can be allocated for future development, i.e., natural capital is transformed into other types of capital, which compensates for the physical loss of natural resources.

Second, some exhaustible natural resources may lose their value due to the use of alternative sources or substitutes.

Third, the economic consequences of depletion (reduced income from the use of mineral resources) can significantly influence the wellbeing of the current generation. Its social and environmental consequences can also have an impact on future generations [23].

The first and second models (Table 1) make it possible to obtain a total assessment of mineral asset depletion based on rent. The first model gives an assessment by years, and the second one assesses depletion continuously, taking into account volumes. Both models are characterized by significant methodological problems. The first problem is the price 
factor in calculating rent. If natural rent is to be correctly calculated, then the resource that has not been yet extracted should be analyzed. As there is no market and neither are there market prices for resources that have not been extracted, it is possible to use the price of end products, intermediate products, or extracted minerals. Accordingly, the costs should be taken as costs for the production of end products, intermediate products, or for the extraction of minerals. The difference between the price and costs is income that includes rent. In the production of several types of products, as well as in the extraction of complex ores, calculations become significantly more complicated.

The second problem is the cost factor in calculating rent. If prices for end products are adjusted, costs should also be adjusted. The problem here lies in different cost structures of production processes (extraction, beneficiation, and processing) and different profitability, which distorts the adjustments. The average cost of extracting a resource in a country can be found only based on corporate reports [64] or the results of company surveys and additional analytical materials because mining companies operate under various geological conditions and therefore have significant differences in the costs they bear. Therefore, when this model is applied at the macro level (for example, a region), statistical data (for example, the information on gross value added in the mining sector) rather than the direct counting method for each MA is used [46].

Third, the depletion period, which is calculated as the ratio between the volume of mineral reserves and annual production volumes, is accepted to be not shorter than 25 years. This period is then taken as the summation interval for the annual values of natural rent.

Fourth, a reasonable proposal to adopt the social norm as a discount rate requires justification.

Depletion assessment in Model 2 is based on the specific depletion of MAs, which makes it possible to take into account excess losses more correctly. In general, the application of Models 1 and 2 can give an estimate of mineral asset depletion over an assessment period or for a volume of mineral reserves, taking into account the identified limitations.

Net price calculation without factoring in the return on investment can be called a rent calculation method at a stretch, as it has the same disadvantages in terms of rent calculations that are associated with the influence of the price and cost factors described in relation to Models 1 and 2. Modified options, in which investments are deducted in full or in part and the rate of return is taken into account, bring it closer to the definition of rent. At the same time, the choice of normal profit as the rate of return is quite controversial. The fact that there are various sources of investment makes the matter more complicated. For example, as a rule, innovations are financed using companies' funds, while prospecting and exploration are financed depending on the stage (search and assessment, prospecting, and exploration are financed using government sources, and additional exploration is financed through company funds). This is not of fundamental importance for the assessment of depletion at the macro level but it is significant for operators and license holders. This method can be recommended for calculating the specific indicator of depletion as the one that is more rent-oriented.

El-Serafy's method develops the idea of the correct assessment of MRD at the macro level as it makes it possible to take into account the interests of not only the current but also future generations. All rent income that is calculated based on the net price is divided into savings and the share that is consumed, which corresponds with the SD concept. This division will depend on the mine life and the selected discount rate.

The stable price method is a new step in the development of the MRD concept as it links this kind of depletion with scientific and technological progress, innovative development, and the emergence of substitutes for minerals. It also uses the idea of income distribution over time depending on the existence of substitutes. However, apart from issues connected with rent, there are other methodological difficulties that lie in the selection of an adequate substitute and the calculation of its price for a variety of mineral resources. These circumstances indicate that this method is quite difficult to apply. 
Among the economic factors of depletion are market conditions for products made from mineral resources, economic performance, price, and production costs. The resource and production factors of depletion include qualitative and quantitative characteristics of MAs (deposits), geological conditions, ore concentration properties, and the opportunity to use the latest mining and mineral processing technology. The institutional factors of depletion include the existence of government programs for the development of individual industries, tax incentives and preferences, and international regulation.

The depletion of complex ores is a particularly difficult issue because not all valuable components of such ores are used due to various reasons. Some mineral resources are fully consumed (for example, uranium, coal, and diamonds), while others are characterized by the opportunity to be partially recovered after consumption through recycling. For the first category of resources, depletion factors include changes in demand, new technologies, and the development of substitutes. For the second category, they include improvements in both the recycling process and the quantitative and qualitative characteristics of the components used in the production process after recycling. The key problem in this case is forecasting the characteristics of advances in science and technology [19].

The presented methods are based on and derive from classical economic profitability accounts. The calculations use four main economic parameters: price, cost, the volume of potential sales, and the rate of return. Despite the methodological and calculation differences, the common denominator of all the described methods is the search for an answer to the question: what is the scope of monetary losses in relation to depletion and the cessation of mining operations? Undoubtedly, this view is correct but it is focused on the goals of the mining company and its owners.

However, it does not take into account the perspective of sustainable development and, thus, other stakeholders' goals. Therefore, the authors of the article propose a broader outlook on the problem of assessing MRD in the context of a cost-benefit analysis, which, by assumption, also allows for the estimation of environmental and social benefits and losses. It is also a long-term perspective that takes into account the aforementioned need to substitute non-renewable natural resources and their national and global economic importance.

MRD will occur if the cumulative negative results associated with restricting access to the resource outweigh the benefits of this restriction (for example, environmental ones), i.e., the losses caused by depletion and suffered by society will be greater than the benefits. In a reverse situation (when benefits exceed costs), the resource is likely to be devalued, i.e., the contribution of mining operations to social wellbeing is estimated to be lower than the benefits that can be brought to society by not using this resource.

It should also be noted that the influence of economic, environmental, and social factors of depletion causes not only economic consequences [65] but also other social and environmental effects $[66,67]$ that cannot be measured using the rent calculation models that were analyzed.

As we view the economic depletion of mineral resources as the impossibility to obtain economic, social, and environmental results from the use of MRs, methods for assessing social wellbeing can be used to assess depletion $[68,69]$. This is especially relevant for countries with RBEs where the mining sector has an impact on many aspects of social and economic development.

\section{Conclusions}

The depletion of MRs should be understood as a decrease in the economic, social, and environmental effects that contribute to social wellbeing which is caused by the disposal of profitable MAs due to the influence of various factors.

The results of the analysis conducted in the course of the study show that the existing MRD assessment methods have significant drawbacks, which is confirmed by the example of calculating indicators for a tin deposit. The most popular depletion assessment methods and models that are based on the concept of rent do not consider the social and 
environmental consequences of depletion and its impact on social wellbeing as a whole, and neither do they cover many different conditions and factors that influence this process.

We believe that MRD assessment should take into account all possible consequences of MRD expressed in monetary terms, which is especially important for countries with RBEs. MRD assessment should be based on rent assessment methods, take into account the multiplier effect, and be supplemented by an assessment of social effects.

Author Contributions: Conceptualization, T.P. and M.N.; methodology, T.P. and I.J.-K.; validation, T.P., M.N. and I.J.-K.; formal analysis, M.N. and I.J.-K.; investigation, T.P. and M.N.; resources, M.N.; writing—original draft preparation, T.P., M.N. and I.J.-K.; writing—review and editing, T.P. and M.N.; visualization, M.N. All authors have read and agreed to the published version of the manuscript.

Funding: This research received no external funding.

Institutional Review Board Statement: Not applicable.

Informed Consent Statement: Not applicable.

Data Availability Statement: No permission required.

Conflicts of Interest: The authors declare no conflict of interest in the results.

\section{References}

1. YUrak, V.V.; Dushin, A.V.; Mochalova, L.A. Protiv ustojchivogo razvitiya: Scenario budushchego. Zap. Gornogo Inst. 2020, 242, 242-247.

2. Kremer, L.; Vinter, G. Ekologicheskoe pravo Evropejskogo Soyuza; Institut Gosudarstva i prava Rossijskoj Akademii Nauk: Moscow, Russia, 2007; pp. 20-135.

3. Efimceva, T.V. Nekotorye Podhody k Resheniyu Voprosov Energetiki i Ekologii v Zakonodatel'stve Integracionnyh ob"Edineniǐ (na Primere Evropeǐskogo Soyuza i Evrazǐ̌skogo Ekonomicheskogo Soyuza). LexRussica 2019, $8 . \quad$ Available online: https: / / cyberleninka.ru/article/n/nekotorye-podhody-k-resheniyu-voprosov-energetiki-i-ekologii-v-zakonodatelstveintegratsionnyh-obedinenii-na-primere-evropei-skogo (accessed on 21 November 2020).

4. A European Strategy for Sustainable, Competitive and Secure Energy. Available online: http://europa.eu/documents/comm/ green_papers/pdf/com2006_105_en.pdf (accessed on 21 November 2020).

5. Communication from the Commission to the European Parliament, the Council, the European Economic and Social Committee and the Committee of the Regions. 2020. A Strategy for Competitive, Sustainable and Secure Energy. Brussels, 10.11.2010 COM (2010) 639 Final. Available online: https:/ / docplayer.net/21077658-Communication-from-the-commission-to-the-europeanparliament-the-council-the-european-economic-and-social-committee-and-the-committee-of-the-regions.html (accessed on 21 November 2020).

6. Communication from the Commission to the European Parliament, the Council, the European Economic and Social Committee, the Committee of the Regions and the European Investment Bank Energy Union Package. A Framework Strategy for a Resilient Energy Union with a Forward-Looking Climate Change Policy, COM (2015) 80 final of 25.02. 2015. Available online: http: / / eur-lex.europa.eu/resource.html?uri=cellar:1bd46c90-bdd4-11e4-bbe1-01aa75ed71a1.0001.03/DOC_1\&format=PDF (accessed on 12 November 2020).

7. Knysh, V.A.; Ivanova, L.V. Cirkulyarnaya ekonomika: Ugroza dlya predpriyatij gornodobyvayushchego sektora ili drajver ih tekhnologicheskogo razvitiya? Gorn. Zhurnal 2020, 9, 33-41. [CrossRef]

8. Amsberg, J. Von Project evaluation and the depletion of natural capital: An application of the sustainability principle Economics. In Environment Working Paper; World Bank: Washington, DC, USA, 1993; Volume 56.

9. Bardi, U.; Jakobi, R. Hiroshan Hettiarachchi Mineral Resource Depletion: A Coming Age of Stockpiling? Biophys. Econ. Resour. Qual. 2016. Available online: https://link.springer.com/content/pdf/10.1007\%2Fs41247-016-0004-x.pdf (accessed on 25 June 2020). [CrossRef]

10. Tsvetkova, A.; Katysheva, E. Present problems of mineral and raw materials resources replenishment in Russia. International Multidisciplinary Scientific GeoConference Surveying Geology and Mining Ecology Management. SGEM 2019, 19, 573-578. [CrossRef]

11. Vinogradov, A.I.; Glushchenko, Y.U.G.; Larichkin, F.D.; Fadeev, A.M. Mineral'no-syr'evoj potencial Severo-Zapada i problema ego racional'nogo ispol'zovaniya, SPb. Zap. Gornogo Inst. 2011, 191, 107-112.

12. Polyakov, V.V. Grozit li Mirovoj Ekonomike Hronicheskij Deficit i Skoroe Absolyutnoe Istoshchenie Mineral'no-syr'evyh Resursov v XXI V.? (Dolgosrochnyj Ekonomiko-Geologicheskij Prognoz Obespechennosti Prirodnym Syr'em). Rossijskij Vneshneekonomicheskij Vestnik 2005, 1. Available online: https:/ / cyberleninka.ru/article/n/grozit-li-mirovoy-ekonomike-hronicheskiy-defitsit-iskoroe-absolyutnoe-istoschenie-mineralno-syrievyh-resursov-v-xxi-v-dolgosrochnyy (accessed on 21 November 2020). 
13. Postanovlenie Pravitel'stva RF ot 15 aprelya 2014 g. N 322 “Ob utverzhdenii gosudarstvennoj programmy Rossijskoj Federacii "Vosproizvodstvo I ispol'zovanie prirodnyh resursov". Available online: http://gov.garant.ru/SESSION/PILOT/main.htm (accessed on 21 November 2020).

14. Report of the World Commission on Environment and Development: Our Common Future. 1987. Available online: https://ru.scribd.com/document/340854798/Relatorio-Brundtland-1987-Report-of-the-World-Commission-onEnvironment-and-Development (accessed on 30 December 2020).

15. Adelman, M.; De Silva, H.; Koehn, M. User cost in oil production. Resour. Energy 1991, 13, 217-240. [CrossRef]

16. El Serafy, S.; Ahmad, Y.; Lutz, E. The proper calculation of income from depletable natural resources. In Environmental Accounting and Sustainable Income; World Bank: Washington, DC, USA, 1989.

17. Osnovnye Napravleniya Byudzhetnoj, Nalogovoj i Tamozhenno-tarifnoj Politiki na 2019 God i na Planovyj Period 2020 i 2021 gg. (utv. Minfinom Rossii). Available online: http://www.consultant.ru/document/cons_doc_LAW_308390/8e2dd0994342861d961 6fc6cb51fd401f8b41f9e/ (accessed on 14 June 2020).

18. Tovarnaya Struktura Eksporta Rossijskoj Federacii so Vsemi Stranami. Oficial'nyj Sajt Federal'noj Tamozhennoj Sluzhby. Available online: http:/ / customs.ru/folder/519 (accessed on 24 June 2020).

19. Carayannis, E.; Cherepovitsyn, A.; Ilinova, A. Sustainable Development of the Russian Arctic zone energy shelf: The Role of the Quintuple Innovation Helix Model. J. Knowl. Econ. 2017, 8, 456-470. [CrossRef]

20. Kovalev, Y. Koncepciya ustojchivogo razvitiya i ee realizaciya v Evropejskom soyuze in Izvestiya Ural'skogo federal'nogo universiteta, Ser. 3. Obshchestvennye Nauk. 2014, 4, 54-65.

21. Ochirbat, P. Ugol'naya promyshlennost' Mongolii: Sostoyanie i perspektivy razvitiya. Zap. Gornogo Instit. 2017, $226,420-427$.

22. Litvinenko, V.S.; Tsvetkov, P.S.; Molodtsov, K.V. The social and market mechanism of sustainable development of public companies in the mineral resource sector. Eurasian Min. 2020, 1, 36-41. [CrossRef]

23. Nedosekin, A.O.; Rejshahrit, E.I.; Kozlovskiy, A.N. Strategic approach to assessing economic sustainability objects of mineral resources sector of Russia. J. Min. Inst. 2019, 237, 354-360. [CrossRef]

24. Kaplunov, D.R.; Ry'lnikov, M.V.; Radchenko, D.N. Usloviya Ustojchivogo Razvitiya Mineral‘no-sy'r'evogo Kompleksa Rossii. GIAB 2014, 1, 3-11. Available online: https://cyberleninka.ru/article/n/usloviya-ustoychivogo-razvitiya-mineralno-syrievogokompleksa-rossii (accessed on 21 November 2020).

25. Uberman, R. Valuation of Mineral Resources in Selected Financial and Accounting Systems. Nat. Resour. 2014, 5, 496-506. [CrossRef]

26. Cherepovitsyn, A.; Ilinova, A. Ecological, economic and social issues of implementing carbon dioxide sequestration technologies in the oil and gas industry in Russia. J. Ecol. Eng. 2016, 17, 19-23. [CrossRef]

27. Special Committee of the Canadian Institute of Mining, Metallurgy and Petroleum on Valuation of Mineral Properties. Standards and Guidelines for Valuation of Mineral Properties (CIMVAL). 2003. Available online: https://mrmr.cim.org/media/1020 / cimval-standards-guidelines.pdf (accessed on 15 June 2020).

28. Santopietro, G.D. Alternative methods for estimating resource rent and depletion cost: The case of Argentina's YPF. Resour. Policy 1998, 24, 39-48. [CrossRef]

29. Evteev, S.A.; Perelet, R.A. Nashe Obshchee Budushchee: Dokl. Mezhdunar. Komis. Po Okruzhayushchej Srede i Razvitiyu (MKOSR); Per. s angl. Progress: Moscow, Russia, 1989; 372p.

30. Baraboshkina, T.A. Istoshchenie poleznyh iskopaemyh. In Rossijskaya Geologicheskaya Enciklopediya. V Trekh Tomah; Izd-vo VSEGEI: Saint-Petersburg, Russia, 2010; Volume 1.

31. Cairns, R.D. Accounting for Sustainability: A Dissenting Opinion. Sustainability 2011, 3, 1341-1356. [CrossRef]

32. Dojze, K.; Gurkov, A. Zapadnaya Evropa Proshchaetsya s Dobychej Uglya. Elektronnyj Zhurnal DW 2015. Available online: https:/ /p.dw.com/p/1HQ5y (accessed on 26 June 2020).

33. Zimakov, A.V. Est' li budushchee dlya ugol'nyh TES v Evrope? Vestn. MGIMO-Univ. 2017, 5, 130-150. [CrossRef]

34. Prusek, S.; Turek, M. Improving the management of a mining enterprise a condition for increasing the efficiency of hard coal production. Inżynieria Mineralna J. Pol. Min. Eng. Soc. 2018, 19, 73-80.

35. Tajduś, A.; Turek, M. The state and conditions of the future functioning of hard coal mining in Poland. Arch. Min. Sci. 2019, 64, 547-559.

36. Arhipov, A.V.; Reshetnyak, S.P. Tekhnogennye Mestorozhdeniya. Razrabotka i Formirovanie; KNC RAN: Apatity, Russia, 2017. Available online: http:/ / www.naukaprint.ru/data/documents/7_arhipov_resh_17.pdf (accessed on 26 June 2020).

37. Muzej geologii Dokembriya. Nauch. zhurn. Institut Geologii KAREL'SKOGO Nauchnogo Centra RAN. Elektron. Zhurn; Muzej geologii Dokembriya: Barit, Philippines, 2017. Available online: http:/ /igkrc.ru/geomuseum/articles/barit (accessed on 28 June 2020).

38. Hotelling, H. The economics of exhaustible resources. J. Political Econ. 1931, 39, 37-175. [CrossRef]

39. Kuznetsov, Y.A.; Semenov, A.V.; Vlasova, M.N. Mathematical modeling of the optimal use of non-renewable natural resources. Econ. Anal. Theory Pract. 2012, 32. Available online: https://cyberleninka.ru/article/n/matematicheskoe-modelirovanieoptimalnogo-ispolzovaniya-nevozobnovimyh-prirodnyh-resursov (accessed on 28 June 2020).

40. Slade, M.; Thille, H. Whither Hotelling: Tests of the Theory of Exhaustible Resources. Annu. Rev. Resour. Econ. 2009, 239-260. Available online: https://www.scirp.org/reference/referencespapers.aspx?referenceid=1250757 (accessed on 15 June 2020). [CrossRef] 
41. Solow, R.M. Intergenerational Equity and Exhaustible Resources. Rev. Econ. Stud. 1974, 42, 29-45. [CrossRef]

42. Boos, A. Genuine Savings as an Indicator for "Weak" Sustainability: Critical Survey and Possible Ways forward in Practical Measuring. Sustainability 2015, 7, 4146-4182. [CrossRef]

43. World Bank Group. The Little Green Date Book (2010-2017). Open knowledge repository. Available online: https: / / openknowledge.worldbank.org/handle/10986/2134/focus?filtertype=author\&filter_relational_operator=equals\&filter= World+Bank (accessed on 10 May 2020).

44. Günseli, B. Toward More Inclusive Measures of Economic Well-Being: Debates and Practices. Labour Organ. (ILO) 2018. Available online: https://www.ilo.org/wcmsp5/groups/public/dgreports/cabinet/documents/publication/wcms_630602.pdf (accessed on 10 May 2020).

45. Danilishin, B.M.; Veklich, O.A. Indikator Podlinnogo Progressa kak Adekvatnyj Makroekonomicheskij Pokazatel' Obshchestvennogo Blagosostoyaniya. Probl. Prog. 2010, 6, 644-650. Available online: https://cyberleninka.ru/article/n/indikatorpodlinnogo-progressa-kak-adekvatnyy-makroekonomicheskiy-pokazatel-obschestvennogo-blagosostoyaniya (accessed on 15 May 2020).

46. Bobylev, S.N.; Minakov, V.S.; Solov'eva, S.V.; Tret'yakov, V.V. Ekologo-Ekonomicheskij Indeks Regionov RF Moscow. 2012. Available online: https://wwf.ru/upload/iblock/dc8/index.pdf (accessed on 10 July 2020).

47. Ericsson, M.; Löf, O. Mining's Contribution to low- and Middle-Income Economies. WIDER Working Paper 2017/148. June 2017. Available online: https:/ / doi.org/10.35188/UNU-WIDER/2017/374-5 (accessed on 10 July 2020).

48. CHernyavskij, S.V.; CHernyavskij, V.S. Klassicheskaya i Sverhpribyl'naya Koncepcii Prirodnoj Renty: Teoreticheskie i Prakticheskie Raznoglasiya v Sovremennom Periode. RPPE 2016, 11. Available online: https:/ / cyberleninka.ru/article/n/klassicheskayai-sverhpribylnaya-kontseptsii-prirodnoy-renty-teoreticheskie-i-prakticheskie-raznoglasiya-v-sovremennom-periode (accessed on 10 July 2020).

49. Cairns, R.D. Economic Accounting in the Simple Hotelling Model. Resour. Energy Econ. 2018, 51, 18-27. [CrossRef]

50. Rubio, V.M. Value and Depreciation of Mineral Resources Over the Very Long Run: An Empirical Contrast of Different Methods. 2005. Available online: https:/ / www.researchgate.net/publication/23548210 (accessed on 30 December 2020).

51. Repetto, R.; Magrath, W.; Wells, M.; Beer, C.; Rossini, F. Wasting Assets: National Resources in the National Income Accounts; World Resources Institute: Washington, DC, USA, 1989.

52. Walls, M. Modeling and forecasting the supply of oil and gas: A survey of existing approaches. Resour. Energy 1992, 14, 287-309. [CrossRef]

53. Accounting for Mineral Resources: Issues and BEA's Initial Estimates. U.S. Department of Commerce, 1994. Available online: https: / /apps.bea.gov/scb/account_articles/national/0494od2/maintext.htm (accessed on 30 December 2020).

54. Volovich, V.N.; Marinina, O.A. E‘konomicheskaya ocenka mineral'no-sy's'evy'x resursov. GIAB 2005, 12. Available online: https:/ / cyberleninka.ru/article/n/ekonomicheskaya-otsenka-mineralno-syrievyh-resursov (accessed on 17 October 2020).

55. Fridman, D.; Orduej, N. Analiz i Ocenka Prinosyashchej Dohod Nedvizhimosti: Per. sangl; Delo: Moscow, Russia, 1995.

56. Tipovye Metodicheskie Ukazaniya po Opredeleniyu, Uchetu, Ekonomicheskoj Ocenke i Normirovaniyu Poter' Tverdyh Poleznyh Iskopaemyh i Soderzhashchihsya v Nih Komponentov pri Pererabotke Mineral'nogosyr'ya. Moscow. 1987. Available online: https: / / files.stroyinf.ru/Data2/1/4293737/4293737207.pdf (accessed on 10 July 2020).

57. Zakon, R.F. “O nedrah” ot 21.02.1992 N 2395-1. Available online: http:/ /www.consultant.ru/document/cons_doc_LAW_343 (accessed on 13 July 2020).

58. Gornorudnaya kompaniya AO «Syrymbet». Oficial'nyj sajt. Available online: http:/ / www.syrymbet.kz (accessed on 30 December 2020).

59. Larichkin, F.D. Otchet NIR; Institut Ekonomicheskih Problem KNC RAN: Apatity, Russia, 2016; 215p. Available online: http: / / www.iep.kolasc.net.ru/larnir2016.pdf (accessed on 30 December 2020).

60. Boyarko, G.Y.; Hat'kov, Y.U. Mirovoj Rynok Olova i Sovremennoe Sostoyanie Olovyannoj Promyshlennosti ROSSII. InternetZhurnal «Cvetnye Metally» 2018, 1. Available online: http://www.rudmet.ru/journal/1691/article/29046/ (accessed on 30 December 2020).

61. Ponomarenko, T.V.; Larichkin, F.D.; Sidorov, D.V. Ocenka perspektiv sozdaniya olovyannoj otrasli v Respublike Kazahstan. Zap. Gornogo Inst. 2016, 221, 742-748.

62. Sokolov, A.D.; Takajshvili, L.N.; Bathuyag, S.; Ochirbat, P. Ugol'naya promyshlennost' Mongolii: Resursy razvitiya. Gornyj Zhurnal 2020, 2, 90-94. [CrossRef]

63. Handbook on Statistics for Economies Based on Natural Resource; Ulaanbaatar City Group: Ulaanbaatar, Mongolia, 2018; 188p. Available online: https:/ / unstats.un.org/unsd/statcom/49th-session/documents/BG-Item3i-ulaanbaatar-city-group-E.pdf (accessed on 10 May 2020).

64. Pashkevich, N.V.; Tarabarinova, T.A.; Golovina, E.I. Problems of reflecting information on subsoil assets in International Financial Reporting Standards. Acad. Strateg. Manag. J. 2018, 17, 1-9.

65. Pashkevich, N.; Tarabarinova, T. Problems of legal and evaluation of the objects of subsoil usage. Vide. Tehnol. Res.-Environ. Technol. Resour. 2017, 17, 216-219. [CrossRef]

66. Marinin, M.; Marinina, O. Improvement of project decisions efficiency and cost optimization at the mine engineering stage of reclamation in the context of open pit ore mining. In Proceedings of the 17th International Multidisciplinary Scientific Geo Conference SGEM 2017, Vienna, Austria, 27-29 November 2017; Volume 17, pp. 423-428. [CrossRef] 
67. Malyshkov, G.B.; Sinkov, L.S.; Nikolaichuk, L.A. Analysis of economic evaluation methods of environmental damage at calculation of production efficiency in mining industry. Int. J. Appl. Eng. Res. 2017, 12, 2551-2554.

68. Averkieva, E.S. Teoretiko-metodologicheskie aspekty issledovaniya obshchestvennogo blagosostoyaniya. J. Econ. Regul. Vopr. Regul. Ekon. 2014, 4, 44-61.

69. SHirov, A.A. YAntovskij Ocenka Mul'tiplikativnyh Effektov v Ekonomike. Vozmozhnosti i Ogranicheniya. EKO 2011, 2. Available online: https:/ / cyberleninka.ru/article/n/otsenka-multiplikativnyh-effektov-v-ekonomike-vozmozhnosti-i-ogranicheniya (accessed on 13 July 2020). 